\title{
Volte-face on controversial French abortion pill
}

\section{Paris}

A RAPID about-turn last week saw the controversial abortion-inducing pill RU 486 taken off the market by its manufacturers, Roussel-Uclaf Laboratories, only to be put back again 48 hours later under pressure from the French Health Minister, Claude Evin. In a ministry communiqué, Evin said that he was acting "in the interest of public health", to uphold women's rights to voluntary abortion under a 1975 statute. He warned Roussel-Uclaf that a 1968 law gave him powers, through the Industry Ministry, to seize the patent for RU 486 (like any other pharmaceutical product judged "essential for public health") and to hand it to another laboratory if the company did not resume production.

Roussel-Uclaf Laboratories decided on 26 October not to go ahead with plans to market RU 486 because of the "emotional reaction of a sector of public opinion in
France and abroad" provoked by news of the drug. These critics say that a black market for the drug will emerge, leading to a trivialization of abortion. The company's decision came just one month after RU 486 was given government approval in France and China for administration under medical supervision (see Nature 335, 486; 1988). It now turns out that anonymous anti-abortionists have threatened company employees and their families, an action which Evin condemned as "scandalous" and "cowardly".

When news of the withdrawal reached a meeting of 9,500 doctors, including EmileEtienne Baulieu who first synthesized RU 486, at the World Congress of Gynaecology and Obstetrics in Rio de Janeiro, there were outraged protests. This response is believed to have encouraged Evin to intervene last Friday. Speaking on French television, he said that "this product does not belong to a laboratory, it

\section{Genentech loses appeal against Wellcome}

\section{London}

GENENTECH has once again lost the fight in Britain over the clot-dissolving agent tissue plasminogen activator (TPA). The British Court of Appeal this week upheld the ruling of the High Court in favour of the British drugs company Wellcome which is challenging the patent held by the US company. Wellcome will greet the decision with satisfaction, but it deals a severe blow to Genentech, coming at a time when sales of TPA are falling short of predictions and questions are being raised over the company's promotion and testing of the drug (see Nature 335, 751; 1988).

This week's decision comes more than a year after the High Court ruling which both sides regarded as a victory. Wellcome said it vindicated its arguments that Genentech's patents failed to meet the criteria of novelty and inventiveness but Genentech lawyer Simon Cooke disagreed, saying that the decision showed that the judge believed the product was novel and inventive.

After Genentech's appeal was dismissed this week, Cooke said that Genentech would decide within the next few weeks whether to appeal to the House of Lords; the court of appeal.granted leave for the company to do so. An appeal would have to be filed before the end of January 1989 and would probably be held next summer. Cooke said he could not comment on the ruling before studying the 317 pages of judgement.

After the initial ruling in the High Court, Cooke said the judge had "misunderstood the technology", and had made a decision that was "fundamentally wrong".

But the Court of Appeal's dismissal of Genentech's claims comes as no surprise to Britain's patent lawyers. "The case was very simple and the court made the right decision", says patent lawyer Iain Baillie. He said Genentech was trying to stop other researchers making the same material through other techniques. The company was being "a little too greedy", and if it appeals to the House of Lords that appeal is unlikely to succeed, he said.

Christine McGourty

\section{Mexican reactor goes on line}

\section{Boston}

After two decades of planning and construction, Mexico's first commercial nuclear power plant came on line last month after the Mexican government gave operators permission to activate one of the two 654-megawatt nuclear reactors in Laguna Verde. The plant, near the Gulf of Mexico in the state of Veracruz, has been completed for months, but it has been the focus of nationwide controversy. Opponents claim that the government waited until after local elections to start up the plant in order to subdue opposition to the reactor.

The opening of the Laguna Verde plant is said to have been met with protests from a coalition of environmental groups, including a permanent vigil outside the reactor site.

Seth Shulman belongs to women".

RU 486 blocks the action of the hormone progesterone, essential at all stages of pregnancy, and has been shown in clinical trials to be safe and reliable in more than 95 per cent of cases, when used with prostaglandins. The French Ministry of Health approval limits distribution of RU 486 to the 800 registered abortion clinics where it is to be given by a doctor only in association with prostaglandins and only within the first 49 days of pregnancy.

The principal advantage of the drug is that it allows some women the option to terminate an unwanted pregnancy without the need for anaesthetic or surgery. But around one in five women could experience excessive bleeding and there is a risk that the fetus would not be expelled. In such cases, women are required, by a Health Ministry stipulation, to undergo surgical abortion, as the surviving fetus could be deformed.

Following approval in France and China, Roussel-Uclaf planned worldwide commercialization of the drug, and applications have already been filed in Britain, the Netherlands, Sweden and Spain. But threats of a campaign by the US Right to Life Committee to boycott Roussel-Uclaf products and those of majority shareholders, Hoechst, together with a strong Catholic anti-abortion lobby in France, led the company's directors to reconsider at an emergency board meeting last week. The strength of conservative Catholic opinion in France has recently made alarming headlines, after cinemas showing Martin Scorsese's film, The Last Temptation of Christ, were subjected to arson and tear-gas attacks.

Restrictive provisos in the French government's approval meant that commercial returns from RU 486 would in any case have been less than RousselUclaf had hoped if overseas markets could not be exploited. Only half of French women seeking abortions would be eligible and the drug's withdrawal is not expected to affect the number of abortions carried out. For the moment, Roussel-Uclaf's about-turn affects only France and no decision has been taken regarding resumption of worldwide distribution, where threats of damage to the company's image through boycotts and adverse publicity remain.

But RU 486 is seen by the World Health Organisation (WHO) as a useful means of birth control to reduce suffering in developing countries. Roussel-Uclaf had already signed a contract to sell WHO the drug at cost price. If necessary, the company says it will give WHO a licence to sell the drug abroad under its own name. Apart from its use as an abortifacient, RU 486 has potential therapeutic value in treating cancers of the prostate, a less controversial prospect that researchers are following up. 